\title{
Advances in Research on Phytophthora capsici on Vegetable Crops in The United States
}

\author{
年 \\ Leah L. Granke and Lina Quesada-Ocampo \\ Michigan State University, East Lansing, MI 48824 \\ Kurt Lamour \\ University of Tennessee, Knoxville, TN 37996 \\ Mary K. Hausbeck \\ Michigan State University, East Lansing, MI 48824
}

Since L. H. Leonian's first description of Phytophthora capsici as a pathogen of chile pepper in 1922 (78), we have made many advances in our understanding of this pathogen's biology, host range, dissemination, and management. $P$. capsici causes foliar blighting, damping-off, wilting, and root, stem, and fruit rot of susceptible hosts (48), and economic losses are experienced annually in vegetable crops including cucurbits and peppers (Fig. 1). Symptoms of $P$. capsici infection may manifest as stunting, girdling, or cankers for some cultivars or crops that are less susceptible (Fig. 2A and B) (99).

$P$. capsici continues to be a constraint on production, and implementation of an aggressive integrated management scheme can still result in insufficient control when weather is favorable for disease (48). Management of diseases caused by $P$. capsici is currently limited by the long-term survival of the pathogen as oospores in the soil (75), a wide host range (28), long-distance movement of the pathogen in surface water used for irrigation (36), the presence of fungicide-resistant pathogen populations (72), and a lack of commercially acceptable resistant host varieties $(119,120)$. As our understanding of $P$. capsici continues to grow, future research should focus on developing novel and effective solutions to manage this pathogen and prevent economic losses due to the diseases it causes.

P. capsici is widespread throughout the United States and the world. In the United States, the pathogen was first described in New Mexico $(78)$ and California $(123,124)$ in the 1920s, in Colorado (11,110), Florida (129), Arizona (16), and New York (130) in the 1930s, in New Jersey in the 1960s $(6,92)$, and in South Carolina (A. P. Keinath, unpublished data), Michigan (48), and Illinois in the 1990s (4). In addition, the disease has been observed in Arkansas, Delaware, Georgia, Hawaii, Kentucky, Louisiana, Massachusetts, North Carolina, Ohio, Oklahoma, Tennessee, and Texas (98). Our research was initiated in the late 1990s when losses caused by $P$. capsici threatened the long-term economic survival of producers of susceptible vegetables in Michigan. Annual losses are still experienced on some farms in Michigan with a history of $P$. capsici despite the use of an integrated management scheme using raised plant beds, plasticulture, irrigation management, and fungicide applications. The narrow profit margin and reliance on mechanical harvesting by the cucumber processing industry greatly

Corresponding author: Mary K. Hausbeck, E-mail: hausbec1@msu.edu

http://dx.doi.org/10.1094/PDIS-02-12-0211-FE

(C) 2012 The American Phytopathological Society limits options for some of the most effective cultural controls (i.e., raised plant beds). Economic management of fruits with long maturation time may be challenging, as fruits are exposed to inoculum for an extended period of time and hence multiple fungicide applications are necessary to protect the fruits. For example, in 2010, a grower experienced $\sim 90 \%$ losses in a 32-ha field of processing squash that was ready for harvest in Mason Co., Michigan (M. Meyer and M. Hausbeck, unpublished). This field was treated with fungicides, but likely after the disease was established. Recent advances in our understanding of the factors that affect pathogen dissemination, disease progress, and management efficacy, as well as future research directions to develop durable and effective management techniques for $P$. capsici will be reviewed.

\section{Wide Host Range}

P. capsici can infect a wide range of hosts under laboratory and greenhouse conditions including cultivated crops, ornamentals, and native plants belonging to diverse plant families (Table 1) (28). In the field, disease is observed annually on cucurbits and peppers and occasionally on tomatoes, eggplant, and snap and lima beans. Laboratory and greenhouse screens provide high disease pressure by using high concentrations of inoculum, providing ideal environmental conditions, and often using young or wounded plants. These conditions increase the probability of disease occurring and may explain why hosts susceptible in laboratory screens may not show symptoms in the field. In addition, minor damage due to $P$. capsici may be overlooked or misdiagnosed in uncommon or unreported hosts.

Differences in host susceptibility may be due to differences in virulence and pathogenicity of the local pathogen population, as $P$. capsici isolates differ in pathogenicity and virulence on different vegetable hosts, and among different cultivars of the same host (e.g., pepper) $(13,62,87,95,100,102,115,131)$. In addition, some isolates are highly virulent on certain hosts or plant parts (i.e., fruit versus roots) and less virulent or avirulent on others $(30,44,99)$.

\section{This Water Mold Is Aptly Named}

Rainfall has been shown to be the most influential environmental factor affecting disease incidence and progress (15), and both free water and force (i.e., falling rain or flowing water) appear necessary for the detachment and dispersal of sporangia (46). Growers and researchers have long recognized that rainfall or excessive irrigation prompts or exacerbates a disease outbreak, and the pattern of disease development typically mirrors the flow of water in the field. Since the pathogen is spread in water, disease may be observed down rows within a field (18), following the flow 
of irrigation water and runoff. The microscopic nature of sporangia and zoospores (Fig. 3B and C) makes it difficult to explain to growers the tremendous reproductive potential of this pathogen under saturated conditions. Hundreds of thousands of sporangia may form on a single infected cucumber fruit (Fig. 3F) (46), each of which may be dispersed and germinate directly to infect new host tissue or may differentiate to form 20 to 40 biflagellate motile zoospores (Fig. 3C) when in contact with free water (48). Swimming zoospores use electro- and chemotactic signals to target plant roots $(76,126)$, and each of these zoospores may potentially cause a new infection (Fig. 3D).

The role of wind in disseminating sporangia from infected tissues may be misunderstood by those managing disease caused by
P. capsici. For instance, growers in the northern part of Michigan believed that their inoculum was coming from infected crops in the southern part of the state because of the timing of the disease outbreaks (i.e., outbreaks were reported in the southern part of the state first). Epidemiological $(46,113)$ and genetic studies $(73)$ have shown that aerial dispersal is relatively unimportant for $P$. capsici. In the 1980s, Schlub (113) conducted an experiment to determine the conditions under which sporangia may be dispersed within a bell pepper field experiencing an active epidemic of Phytophthora blight. Aerial sporangial dispersal was observed very rarely, and was associated with either rain, overhead irrigation, or sporangial dissemination over distances less than $5 \mathrm{~cm}$. Since many growers still misperceived that sporangia could be spread farm-to-farm via

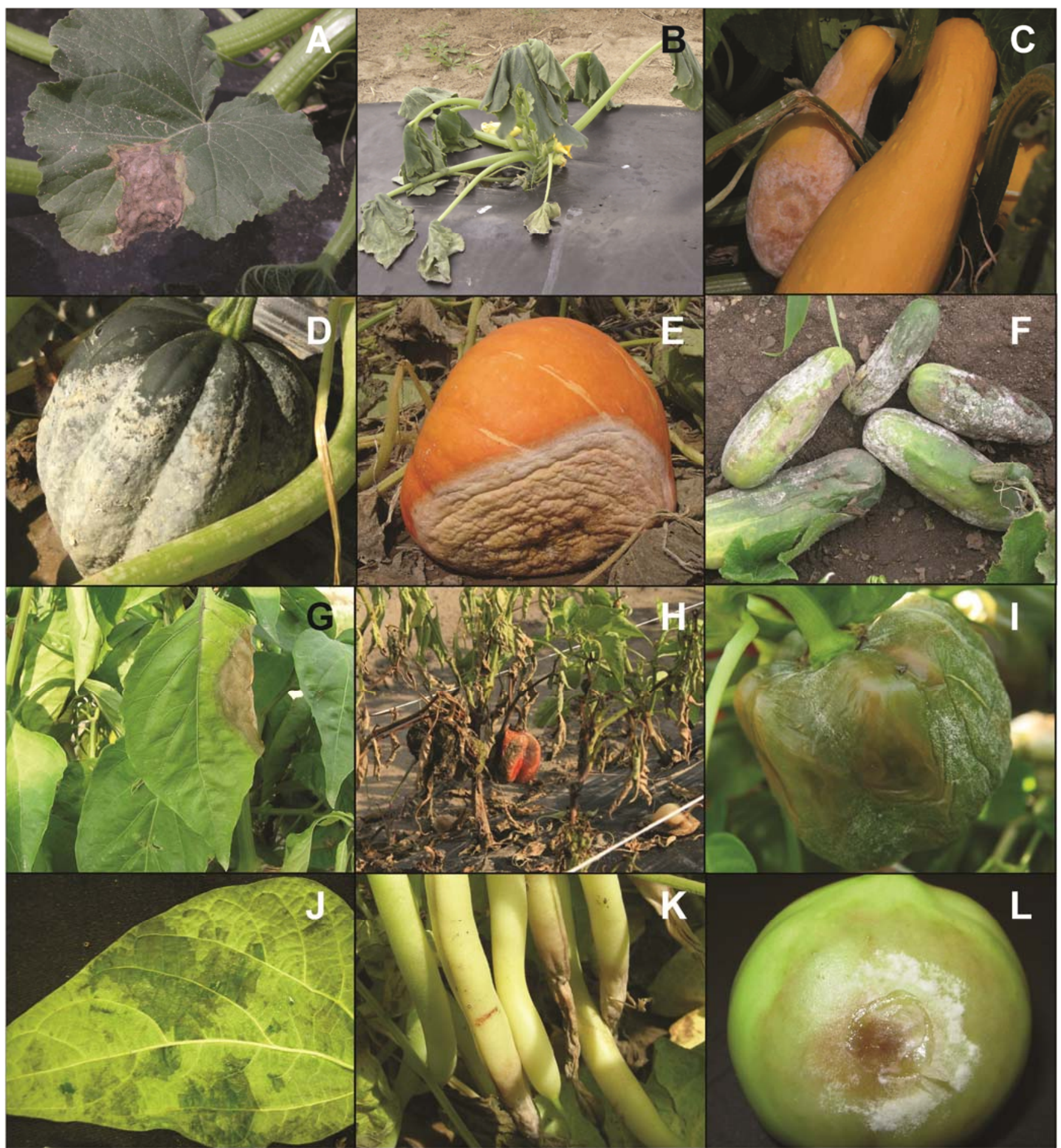

Fig. 1. Symptoms of disease caused by Phytophthora capsici include foliar blighting (A, G, J), root and crown rot (B, H), and fruit rot (C to F, I, K, L). Cucurbits such as summer squash (A to $\mathbf{C})$, hard squashes (D and E), and cucumbers $(\mathbf{F})$ are susceptible as well as peppers ( $\mathbf{G}$ to $\mathbf{I})$, snap bean ( $\mathrm{J}$ and $\mathrm{K})$, and tomatoes $(\mathbf{L})$. 
the wind, a study was conducted in Michigan in the early 2000s to characterize $P$. capsici populations from six farms in four different vegetable growing regions in Michigan. The results of that study

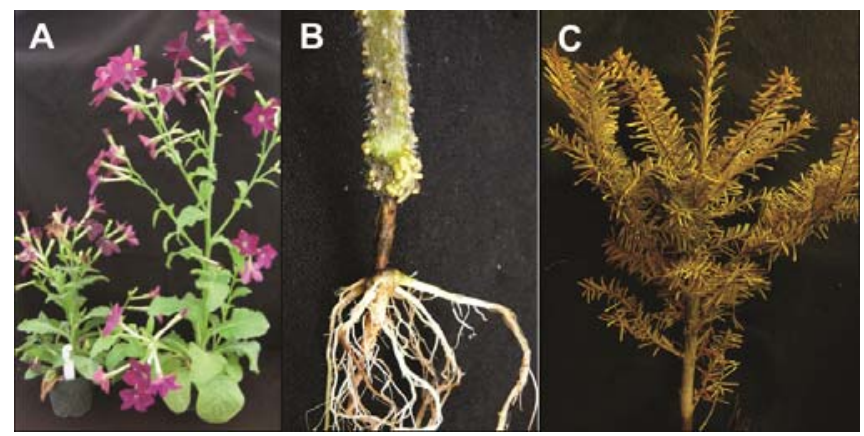

Fig. 2. Phytophthora capsici causes stunting in ornamental tobacco (A), girdling in a tomato cultivar with tolerance to Phytophthora root and crown rot (B), and bronzing of Fraser fir needles (C). indicated that $P$. capsici persists in Michigan fields as reproductively isolated outcrossing populations, suggesting that $P$. capsici was not being disseminated field-to-field (73). To further clarify this issue, a laboratory study directly examining the effects of wind and water on $P$. capsici sporangia was conducted (46). Simulated wind (5 liters/min airflow) did not detach sporangia from host tissue (Fig. 4A and B), but sporangia were easily detached and transported in water with capillary force (Fig. 4C and D). When atmospheric sporangial concentrations were monitored in a field with infected acorn squash and cucumbers, few sporangia were detected even when copious amounts of sporangia were present on infected fruits. Airborne sporangial concentrations were positively associated with rainfall, but not with wind speed or other environmental conditions (46). While $P$. capsici is unlikely to be moved field-to-field via the wind, the pathogen may be moved between locations when growers use surface water sources for irrigation (36) or through the movement of infected plant material and infested soil.

Infested irrigation water has been recognized as an important source of inocula for oomycete plant pathogens including $P$. cap-

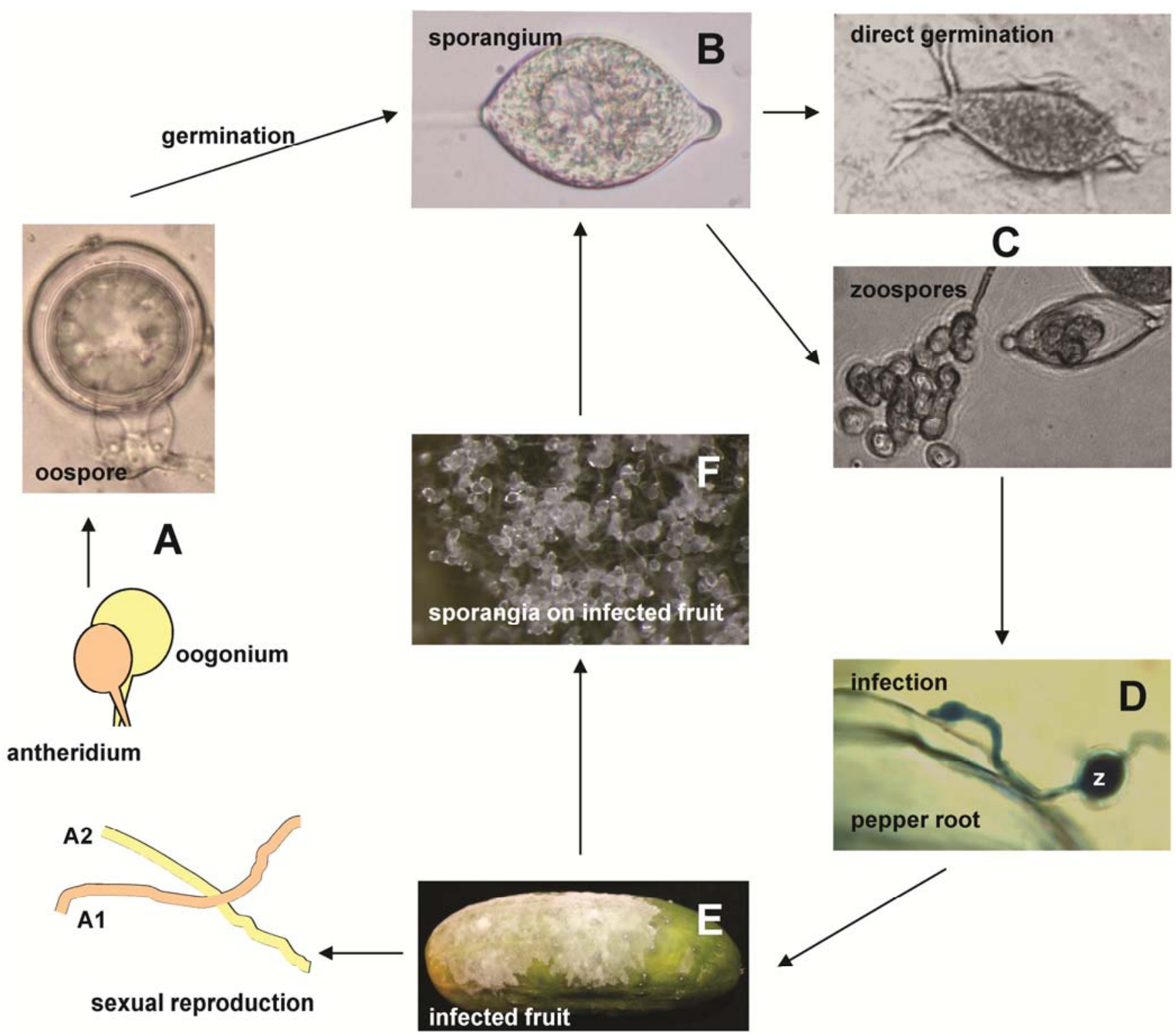

Fig. 3. Disease cycle of Phytophthora capsici on cucumber. When both mating types are present in the same field, oospores are produced (A), which allow $P$. capsici to overwinter and survive for years in the soil even in the absence of a susceptible host. Dormant oospores germinate to produce lemon-shaped sporangia (B) during wet conditions. Each sporangium (B) may germinate directly or via the formation of 20 to 40 bi-flagellate swimming zoospores (C) to infect the host (D). Sporangia are dispersed via irrigation water or wind-blown rain from one plant to another. Zoospores may swim in soil water toward plant roots, encyst, and germinate to penetrate the host (D). As the pathogen colonizes the host $(\mathbf{E})$, copious amounts of sporangia $(\mathbf{F})$ form on the host, which are able to infect new plants or new parts of the same plant causing multiple cycles of infection during a single growing season. 
Table 1. Reported hosts of Phytophthora capsici (modified from Erwin and Ribeiro [28])

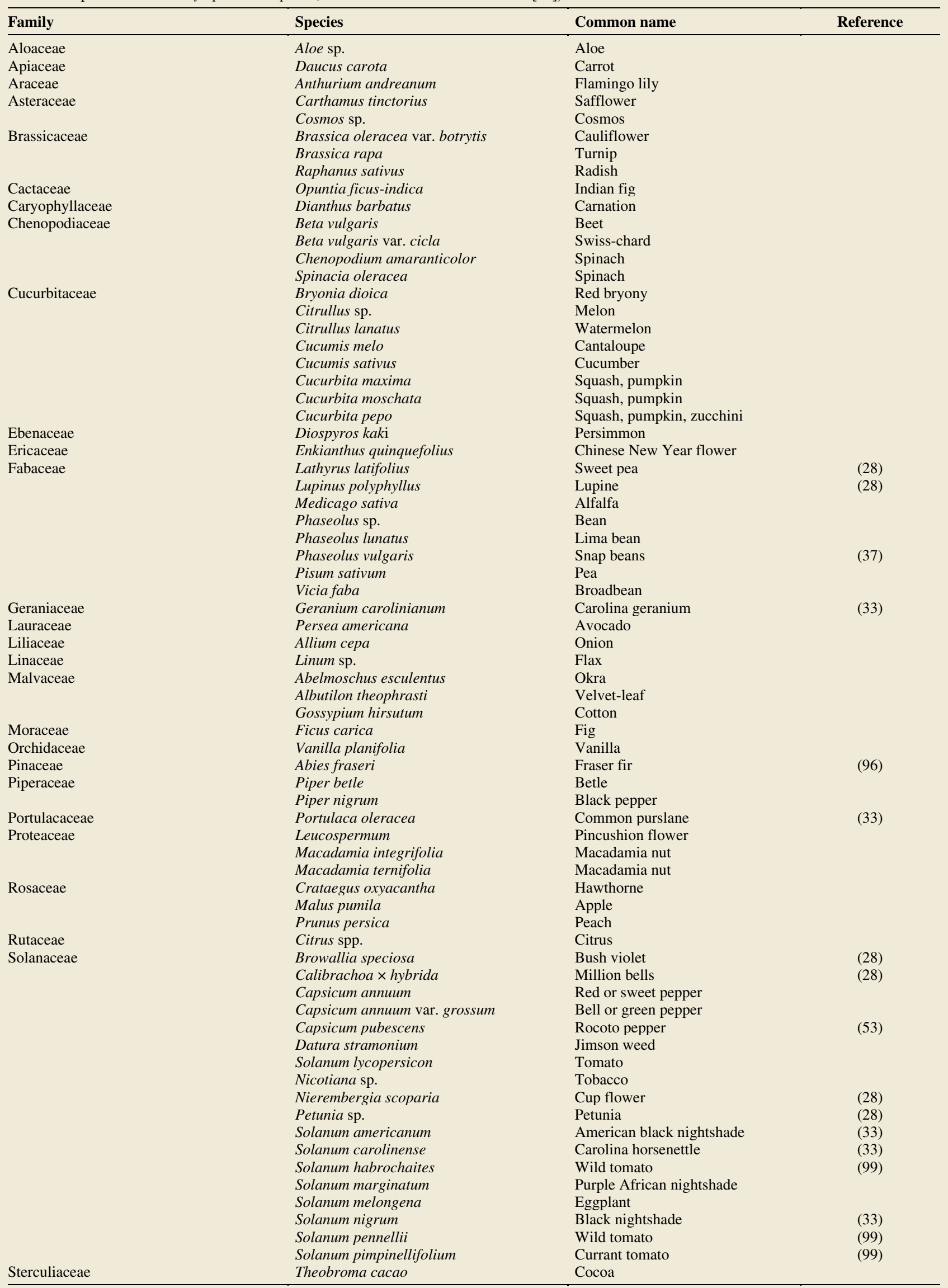


sici $(36,108,128)$. It is our opinion that contaminated surface water was a significant contributor to the increase in incidence of infested fields and associated crop losses over the last 20 years in Michigan. $P$. capsici has been detected in rivers, creeks, ditches, and ponds fed by canals, streams, and surface runoff water in Michigan (Fig. 4E), Florida, and Georgia $(36,108,128)$. Studies in Michigan (36) and Georgia (128) found that host fruits (cucumbers and eggplants, respectively) were more sensitive baits than pears for the detection of $P$. capsici (Fig. 4F). In Florida, filtration and baiting with lemon leaves yielded low recovery of $P$. capsici, but the pathogen could be detected occasionally (108). Wang et al. (128) found that retrieval of $P$. capsici from pear and eggplant baits could be improved by inoculating pepper stems with infected bait tissue and isolating the pathogen from the pepper stem as compared to direct isolation from the bait onto agar. Surface water contaminated with $P$. capsici can be a source of inocula for fields planted to susceptible crops (36), resulting in nearly uniform crop infection. When a creek used for irrigation on a farm in southwest Michigan was monitored, $P$. capsici could be detected yearly even after the grower transitioned from cucumber production to the production of potatoes and field crops (97). The monitoring site was near the source of the creek, upstream of other vegetable farms in the area. Yearly changes were observed in phenotypic traits (mating type and sensitivity to $100 \mathrm{ppm}$ of the fungicide mefenoxam) and genetic structure of populations. Isolates with the same haplotype were detected over multiple years, suggesting that the pathogen could be surviving overwinter in irrigation water or infested soil was being washed into the creek from adjacent fields annually. Shared multilocus haplotypes were also observed for isolates collected from the field and water, suggesting that isolates from the field were contributing to populations in the water (via runoff) or that isolates in the water were contributing to populations in the fields (via irrigation) (97). In Georgia, no more than two genetic

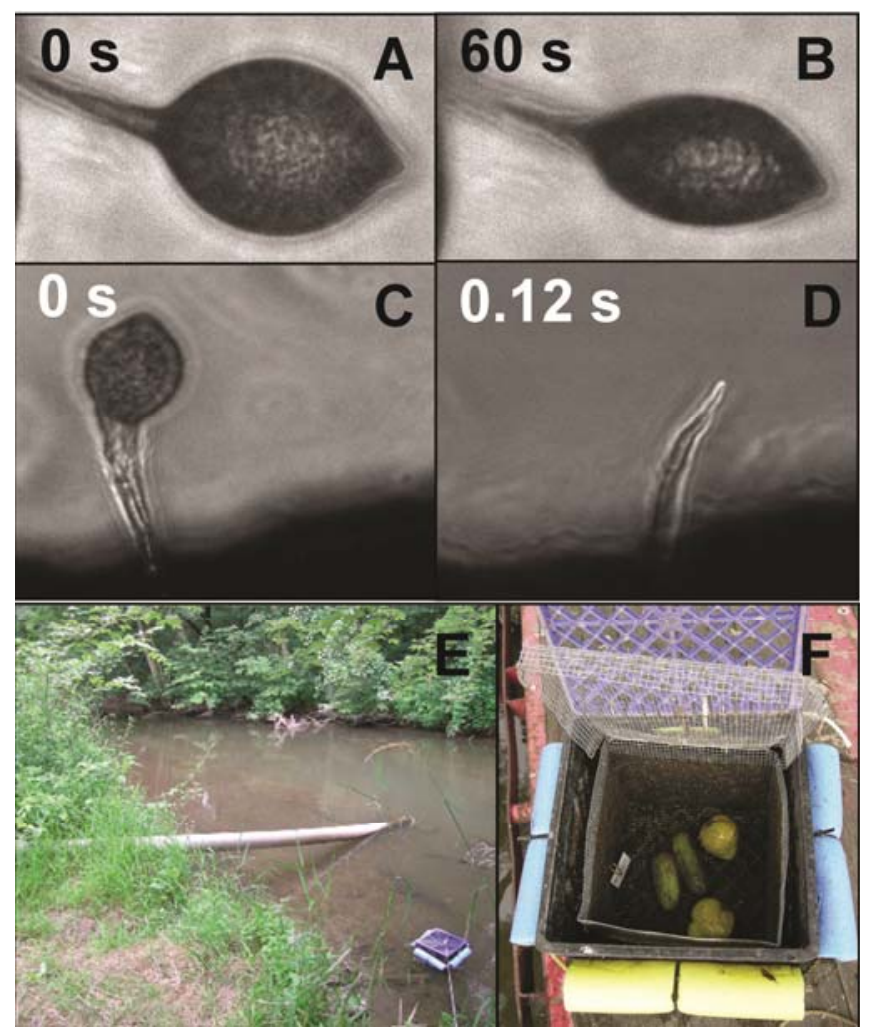

Fig. 4. A Phytophthora capsici sporangium before (A) and after (B) exposure to $60 \mathrm{~S}$ of simulated wind and a sporangium before (C) and after (D) exposure to water with capillary force, demonstrating that $P$. capsici sporangia need to be in contact with free water to detach from the host and be transported. Sporangia are easily dispersed in water and may be detected in surface water used for irrigation (E) by baiting for the pathogen using susceptible host fruits such as cucumbers and pears $(\mathbf{F})$. groups were detected for a $P$. capsici population in a single irrigation pond, and no shared genotypes were observed between ponds on different farms when populations were monitored for a single field season (128). Chlorine (49) and algaecides (43) were effective to treat infested irrigation water in laboratory trials, but have not been tested in the field. Growers of susceptible crops should avoid surface water for irrigation to prevent the introduction of $P$. capsici to new areas and to prevent the introduction of new strains of $P$. capsici that may have increased virulence or decreased fungicide sensitivity to an area with an existing $P$. capsici problem.

In addition to pathogen dissemination in contaminated surface water via irrigation $(48,53)$, fields may become infested with $P$. capsici via movement of infested soil on equipment, disposal of infected cull fruits onto fields, waste and runoff water, and infected transplants. Although movement of the pathogen via equipment to a new field or within fields is likely, in Michigan we've observed this mode of dissemination to be less important compared to the dumping of infected culls or the use of contaminated irrigation water. Over several growing seasons, we've observed that when growers who have one or more $P$. capsici-infested sites purchase or rent new parcels that have not hosted vegetables to anyone's knowledge, the first disease symptoms are detected on those parcels in approximately 5 years. The pathogen is likely introduced through equipment shared with neighboring fields that are infested with P. capsici. Tilling diseased cull fruit into field soils serves as an effective means of either introducing the pathogen into a previously noninfested site, or increasing the inoculum level. As mentioned above, infested irrigation water is a very effective means for pathogen dissemination. When a widespread disease outbreak occurred in a vegetable field in southwest Michigan the first year that vegetables were planted there, irrigation water was suspected as the source of inoculum (36). In the past, some vegetable processing facilities disposed of waste wash water on fields, which is unadvisable based on our current knowledge of $P$. capsici spore survival and dissemination in water. Depending on drainage patterns, surface water runoff from adjacent farms that are infested with $P$. capsici may allow for pathogen spread field-to-field and farm-tofarm. With the use of direct field seeding for many cucurbit crops or the use of greenhouse-grown transplants for field establishment, the potential for $P$. capsici being introduced to a field via transplants is minimized. The threat of introducing $P$. capsici via transplants was much higher in previous decades when bundles of fieldgrown, bare-root tomato and pepper transplants would arrive in Michigan and other northern growing regions from the southern United States for use in establishing production fields.

Recently, there has been some interest in invertebrates as potential vectors for $P$. capsici. While adult shore flies and the larval stage of fungus gnats and shore flies ingested $P$. capsici sporangia, the sporangia were no longer viable following excretion (55). Oospores have been observed in the guts of fungal gnat larvae, but the viability of excreted oospores was not determined (48). Currently, there is no evidence that invertebrates play a role in the spread of $P$. capsici within or between fields. However, oospores survived in the guts of both fungus gnats and shore flies, and these insects were able to transmit Pythium aphanidermatum to greenhousegrown cucumber $(41,57)$. Future studies may further clarify whether or not invertebrates contribute to $P$. capsici dissemination within and between fields.

\section{Sexual Reproduction and Oospores}

Sexual reproduction is the primary source of genotypic variation in nature. Since $P$. capsici is heterothallic, both mating types (A1 and A2) are required to be in direct contact for oospore production (Fig. 3A) on or within host tissue $(66,125)$. Both mating types have been found in single fields in many areas of the United States including California (38), Florida (94), Georgia (131), Illinois (56), Kentucky (86), Massachusetts (91), Michigan (73), New Jersey (93), New York (25,39), New Mexico (29), North Carolina (92), Tennessee (24), and Texas (34). When oospores are formed, the pathogen is able to survive long-term and overwinter in the soil 
even in the absence of a susceptible host. A study in Michigan provided evidence that oospores survived a 5-year rotation to corn and soybeans to initiate a new epidemic when a susceptible crop was planted again (73). A study in Florida found that P. capsici survived in soil for at least a year and likely longer (32), providing evidence to support the assumption that oospores were responsible for year-to-year survival in infested fields.

Oospores are capable of germinating, even in the absence of nutrients, to give rise to mycelia and/or sporangia (Fig. 3A) $(7,28,50)$. Phytophthora oospore germination is affected by length of dormancy period, nutrition, light, temperature, soil water matric potential, chemical treatments, and treatment with enzymes $(14,50,101)$. Generally, oospores require a dormancy period of at least 1 month $(28,112)$ before germinating directly or by forming sporangia, the asexual spores responsible for rapid and polycyclic disease development (Fig. 3B to F).

\section{Genetic Diversity and Population Dynamics}

Variation in colony morphology, sporangial shape and size (Fig. $5 \mathrm{~A}$ to $\mathrm{C}$ ), pedicle length, optimum growth temperature, and sporangial production have been observed within $P$. capsici $(3,12,56,85,102,118)$. Sporangial shape and size may vary within a single culture of an isolate. Chlamydospore production is relatively uncommon in $P$. capsici, but chlamydospores have been observed in liquid culture for some isolates from nonvegetable $(12,85)$ and vegetable hosts $(45,56)$. The morphological characteristics defining $P$. capsici are inclusive of several closely related species, and molecular studies have defined what constitutes $P$. capsici sensu stricto and have assisted finding new species $(85,98)$. Several phylogenetic studies have focused on better understanding the $P$. capsici species complex, and new species closely related to $P$. cap- sici such as $P$. tropicalis have been found $(3,24,85,88,89)$. Nonetheless, recombination present in genes commonly used for phylogenetic studies as well as small sample sizes that do not truly represent the genetic variation found in $P$. capsici in nature have somewhat obscured the evolutionary relationship of $P$. capsici with its sister species.

Population studies have been more successful than phylogenetic studies in increasing understanding of the distribution of genetic variation as well as some of the evolutionary forces shaping $P$. capsici populations $(73,74,97,98)$. Populations of $P$. capsici have been previously studied at a local scale within states in the United States $(33,73,121,128,131)$, and within countries where this pathogen is economically important $(80,115,118)$. Isolates and populations have been analyzed using a wide range of phenotypic and molecular markers. Most recently, these include surveys of diversity using randomly amplified polymorphic DNA (RAPD) markers and single nucleotide polymorphism (SNP) markers $(40,131)$. Frequently, these studies focused on a particular region and determined that clonal lineages of $P$. capsici are confined in space to single fields and in time to single years $(72,97)$. Nonetheless, recent investigations indicate that the overall genetic diversity of $P$. capsici at specific sites and across entire regions can vary dramatically. For example, in the United States, the population genetic diversity appears to be driven by the sexual stage and the production of oospores as dormant propagules, which is reflected in very high levels of genotypic diversity (40). This is in contrast to populations in Peru and Argentina where wide sampling over multiple years suggests that clonal lineages are dominant $(40,52)$. In Peru, populations at coastal locations had very little diversity and were dominated by a single A2 mating type clonal lineage. In Peru, susceptible hosts are grown year-round, and there does not

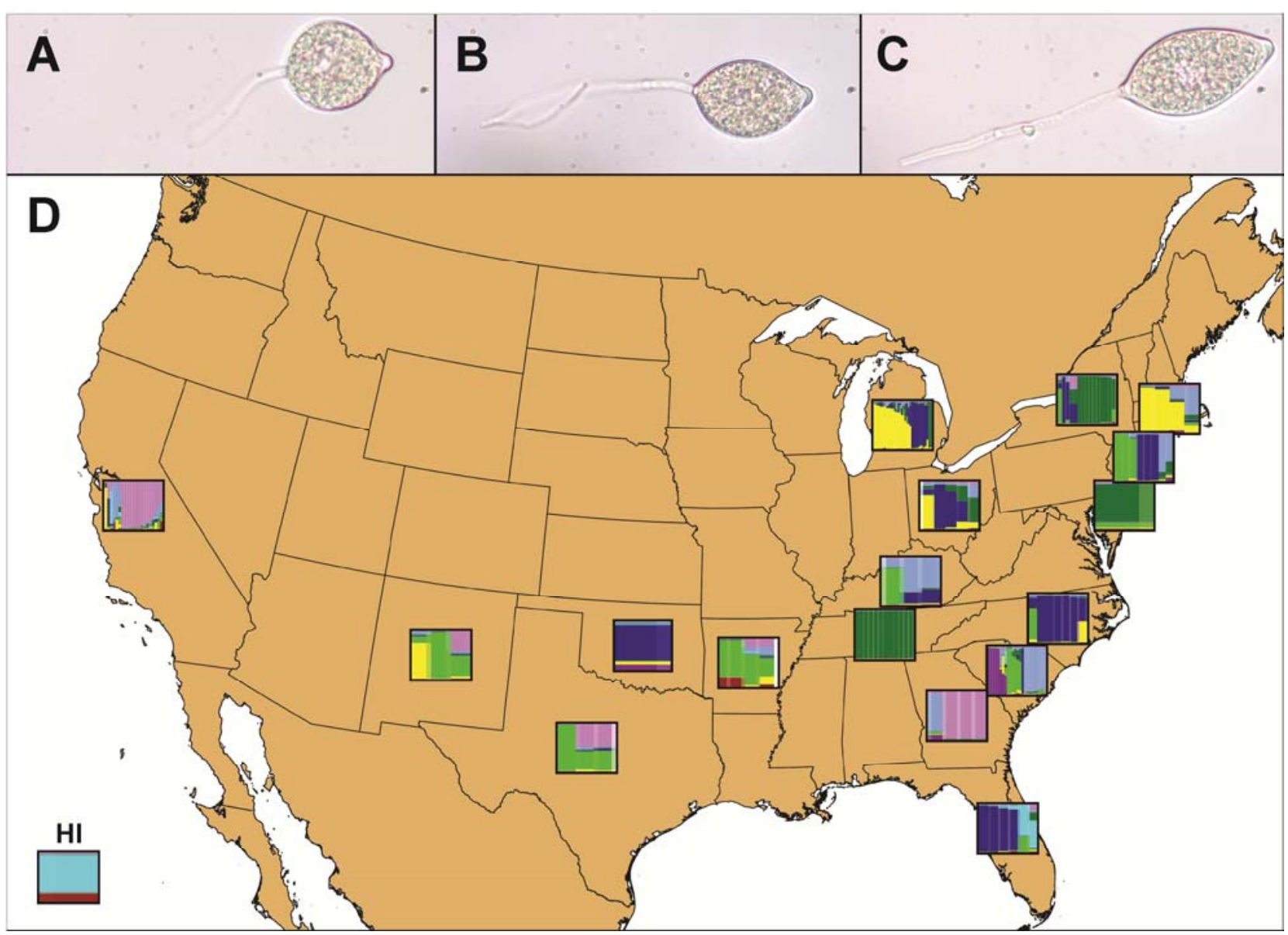

Fig. 5. Within Phytophthora capsici, much variation has been observed in sporangial morphology (A to C). Populations of $P$. capsici in the United States are very diverse (D). Within our sampling of isolates from the United States, eight genetic clusters were detected using Bayesian clustering (each cluster is represented by a different color). Each isolate is represented by a bar, which is partitioned into colored segments that represent the individual's proportionate genetic membership in a given Kth cluster. 
appear to be a strong selection pressure for sexual reproduction and subsequent formation of dormant oospores in the coastal areas sampled, as the A1 mating type was not detected in this sampling. There was slightly more diversity for populations in the Amazon high jungle with both mating types present in some fields (52). Nonetheless, the coastal clonal lineage dominated these sites, too. In Argentina, a single A1 mating type clonal lineage was found at widely separated locations across multiple years. Here crops are not present year-round and evolutionary mechanisms driving the survival and spread of this lineage are not clear (40).

A recent study using hundreds of isolates from locations worldwide and diverse hosts has confirmed the high genetic diversity of $P$. capsici at a global scale and detected the presence of population structure by geography (Fig. 5D) and by host (98). This was in agreement with previous investigations documenting differences in pathogenicity of isolates from cucurbitaceous and solanaceous hosts (102), and that P. capsici is not wind dispersed, creating geographically isolated subpopulations (46). Finding genetic stratification in $P$. capsici populations by geography and host highlight the importance of including isolates from different subpopulations that represent the genetic variation in $P$. capsici for development of diagnostic tools, fungicides, and host resistance. Management can be tailored to control local populations of $P$. capsici; nevertheless, this approach requires a detailed knowledge of regional pathogen population structure and distribution. A pathogen like $P$. capsici with a mixed type of reproduction has a high probability of evolving rapidly and overcoming fungicides or resistant host varieties (83). New genotypes are created through recombination that occurs during sexual reproduction, and alleles in surviving isolates will be selected for and established by asexual reproduction, which could multiply the number of genotypes with fungicide resistance and increased virulence. It is important to determine the genotype and phenotype (virulence, resistance to fungicides) of strains present in a particular region and prevent the introduction of plant tissue infected with exotic strains. These new strains could be responsible for initiating devastating epidemics by increasing genetic variability, which could include hard-to-control strains.

An additional concern that has not been widely addressed is the possibility of $P$. capsici forming hybrids in nature with other species. Hybrids between Phytophthora spp. have been produced under laboratory conditions and found to have an expanded host range in comparison to the parental strains that originated them (27). Population structure analysis of P. capsici, P. tropicalis, and isolates closely related to both species revealed some shared polymorphisms between $P$. capsici and $P$. tropicalis (98). The observed shared admixture could be due to ancestral polymorphism or to recent recombination events given that it is possible to obtain interspecific progeny under laboratory conditions when $P$. capsici and $P$. tropicalis are crossed (24); however, no hybrids have been characterized from nature. Nonetheless, the finding of a set of isolates that formed a subpopulation clearly differentiated from, but closely related to, $P$. capsici and $P$. tropicalis isolates (98), highlights the importance hybridization could have in the evolution of this Phytophthora clade.

\section{Managing $P$. capsici Requires \\ an Aggressive and Integrated Approach}

Management of diseases caused by $P$. capsici is expensive and difficult, and growers may be reluctant to adopt practices that require a significant investment. We emphasize to growers in Michigan that monitoring irrigation to prevent over-watering and using clean water sources is of utmost priority. If a site is infested with $P$. capsici, a combination of a lengthy crop rotation, soil fumigation, subsoiling or other tillage methods to increase drainage, using raised ( 8 " or higher) plant beds with black plastic mulch, trickle irrigation using well water, host resistance, frequent fungicide applications targeted at the appropriate susceptible plant site, destruction of infected plants, and early harvest may be necessary to manage the disease (Fig. 6). Management schemes should be tai- lored to fit the production system. For instance, while smaller fruits produced for the fresh market may be trellised to avoid contact with infested soil (1), large fruits that cannot be trellised may be planted into mowed cover crops to reduce splash dispersal of inocula. Cultural modifications of the system are less feasible for fruits produced for the processing market due to a small profit margin and the use of mechanical harvesters (48). During periods of high rainfall, crops may be lost despite aggressive management of the disease. In areas of the United States with low annual rainfall, irrigation management may be sufficient to manage the diseases caused by $P$. capsici.

Crop rotation. While crop rotation is still recommended as a component of a disease management plan, the efficacy of crop rotation is limited due to the long-term survival of oospores in the soil $(15,32)$. Several-year crop rotations have not been successful as a stand-alone tool to manage diseases caused by $P$. capsici (75). It appears that oospores can survive and initiate new epidemics in vegetable production fields in Michigan, even when those fields are rotated to a nonsusceptible host for 5 years or more (73). As new hosts of $P$. capsici are described, the options available for crop rotation diminish. In the mid-2000s, Phytophthora rot and blight were observed on snap bean (Fig. 1J and $\mathrm{K}$ ) in several counties in Michigan (37). Previous to this, snap beans, dry edible beans, and soybean were grown in rotation with cucurbits in Michigan, but all of these crops were shown to be susceptible under laboratory conditions (37). Disease on snap beans in commercial production fields in New York (84) and Connecticut (69) was also reported in 2008 and 2009, respectively. Pod rot of lima bean was observed in commercial production fields in Delaware, Maryland, and New Jersey in 2000 (23) and has continued to be a problem in these areas (22). Fungicide options are limited for snap and lima bean growers, and the low profit margin of beans produced for the processing market makes the additional costs associated with fungicide applications unsustainable for many bean growers. In addition, isolates collected from snap (37) and lima (22) beans showed a range of response to the fungicide mefenoxam, one of the few fungicides registered for Phytophthora control on bean, and resistant isolates were characterized. Beans are no longer recom-

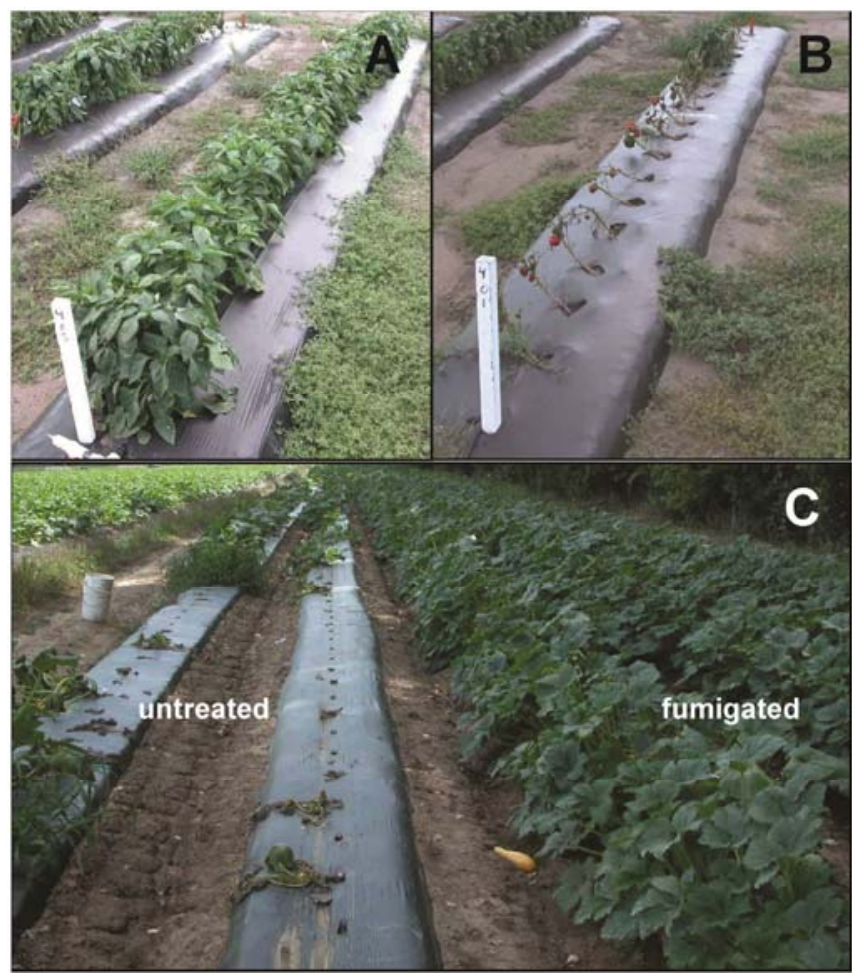

Fig. 6. Good control of Phytophthora crown rot may be achieved by applying fungicides through the drip irrigation system (A) as compared to no fungicide treatment (B). Plant survival is enhanced in fumigated soil versus untreated soil (C). 
mended as a rotational crop to manage diseases caused by $P$. capsici (37). Isolates of $P$. capsici obtained from infected beans were highly virulent to pepper, tomato, zucchini, and cucumber fruits in a laboratory screen (44).

Survival of the pathogen in undescribed hosts may allow the pathogen to persist during crop rotation. In western Michigan, growers began rotating fields that were abandoned for vegetable production due to problems with $P$. capsici to Fraser fir production for the Christmas tree market. When Fraser fir seedlings were planted in a $P$. capsici-infested field, most developed disease symptoms (Fig. 2C), and the pathogen was recovered from root tissue (96). Hence, while other Phytophthora spp. are currently of more concern for Phytophthora rot of Fraser fir (8), P. capsici may survive in fields rotated from vegetable to Christmas tree production. In addition, $P$. capsici was occasionally isolated from several weed species retrieved from commercial vegetable fields in Florida (33), and two weed species were susceptible under greenhouse conditions in a study in Illinois (122), suggesting that weeds may serve as alternate hosts for $P$. capsici in some regions.

Cultural control. Cultural techniques should focus on limiting soil saturation and water accumulation and movement within a field. Rainfall and excess soil moisture are the most important factors contributing to initial infection and the spread of $P$. capsici $(14,15,103,104,106,113,116)$. When heavy rainfall $(>2 \mathrm{~cm})$ occurs, severe disease may develop even in well-drained fields as sporangia are dispersed by wind-driven rain (46) and the flow of runoff water may distribute inoculum down rows $(48,105)$, especially in flat-ground production. Growers are encouraged to plant into welldrained fields; to accomplish this, tillage or drainage system construction may be necessary. Planting into raised beds can prevent soil moisture accumulation at the base of plants (Fig. 6A and B). Covering raised beds with plastic mulch is desirable to increase yield $(48,107)$, reduce weed pressure, and prevent bed wash-out during intense rain events. Raised beds may not be practical for crops produced for the processing market due to a low profit margin and the use of mechanical harvesters (48). To limit water splash in these systems, growers may utilize mowed cover crops on bare soil or straw mulch between rows $(48,81,105)$.

Planting into a mowed wheat cover crop can reduce splashing of P. capsici-infested soil onto plant material and was shown to lower disease incidence and pathogen spread as compared to bare soil in a previous study in pepper in North Carolina (107). A yield advantage was not observed for peppers planted into wheat stubble, but improved yields were observed for peppers planted into raised beds with polyethylene mulch (107). Plasticulture was shown to increase disease incidence and pathogen spread in pepper when sporulating fruits were placed on top of the mulch and rainfall occurred. The plastic mulch allowed the pathogen to spread quickly down rows (107). Similarly, higher yields and larger fruits were obtained from peppers planted into a raised bed with polyethylene plastic mulch than in raised beds with surface living and organic mulches, even though plant death was greater in polyethylene plots in unreplicated field trials in Florida. When these plots were seeded with butternut squash following the removal of the pepper crop, no differences in yield were observed between treatments (109). For watermelon, no significant differences in disease were observed when planted into plastic-covered raised beds in comparison to bare ground raised beds in a South Carolina study (67). Another study in Florida documented that planting into no-till Sunn Hemp or Iron-clay pea debris resulted in a higher incidence of Phytophthora blight of pepper than planting into solarized or fumigated soil in raised beds covered with polyethylene mulch (20). A reduction in Phytophthora blight of pepper was observed following incorporation of urban plant debris (20), composted cow manure (61), or mustard or canola (58), an increase was observed following the incorporation of cotton gin trash (79), and no obvious benefit or detriment was observed following the incorporation of sewage sludge, yard trimmings, wood chips, crab shell waste, or humate (63). Adding a biocontrol agent such as Trichoderma hamatum (61) or Bacillus (59) to compost may improve disease control. Compost water extracts showed variable results, with some showing negative effects on zoospore germination, germ tube elongation, mycelial growth, and pathogen populations, and others showing no activity (111). Hence, the role of soil amendments and composts in suppressing Phytophthora diseases is still unclear.

Managing irrigation is key to reducing the spread of $P$. capsici within a field. Traveling overhead irrigation systems that produce larger irrigation droplets may result in fruit being splashed with contaminated soil (81). Subsurface drip irrigation is generally a better option to lessen diseases caused by $P$. capsici. In areas of the United States with low annual rainfall, growers can impact disease severity through irrigation management. In California, it was shown that watering summer squash less frequently ( 21 days compared to 7 days furrow irrigation) resulted in decreased disease incidence as opposed to watering more frequently. In the absence of disease, there was no yield advantage to more frequent irrigation. They also showed that irrigation can be reduced to a minimum after fruit set and eliminated before harvest with no reduction in yield (18). In pepper, placing drip irrigation emitters away from the stems of plants reduced Phytophthora crown rot of peppers in California (17), a region that receives little annual rainfall during the time that peppers are grown. A reduced frequency drip irrigation schedule (as needed versus three times per week) also reduced Phytophthora crown rot of pepper (103) and P. capsici soil population densities (104) in North Carolina, a region that receives significant rainfall.

Host resistance. Host resistance is a desirable element in an integrated management scheme due to its ease of use and lack of environmental impact. Susceptibility varies depending on the host type, cultivar, plant part, and environmental conditions. For instance, zucchini and yellow summer squash fruits were more susceptible than melon, watermelon, cucumber, winter squash, and pumpkin fruits in a laboratory screen (2). Within each fruit type, a wide range of disease responses may be observed between susceptible and tolerant cultivars for fruit rot $(26,77)$ and root and crown rot $(30,99)$. Resistance to root and crown rot in pepper are governed by different genetic mechanisms than resistance to fruit rot or foliar blighting (117). Plant/fruit age also affects susceptibility for pepper plants (64) and cucurbit $(2,35)$ and pepper fruits (10). Generally, disease is more severe on younger/smaller fruits and plants. Wounding has been shown to negate age-related resistance in pepper (10) and pickling cucumber (42) fruits.

Tolerance has been identified in cucumber (35) and pumpkin (77), but no sources of high or complete resistance to $P$. capsici have been identified. Some squash (90), tomato (99), and pepper (30) varieties show complete resistance to $P$. capsici, but have unappealing horticultural characteristics. Some pepper (Fig. 7A) and tomato varieties have tolerance to crown rot caused by $P$. capsici along with good horticultural traits, and are grown in $P$. capsici-infested fields $(31,99)$. However, some growers may be reluctant to use commercial bell pepper cultivars that possess tolerance to $P$. capsici because of poor fruit shape and a perceived increase in silvering (65), the separation of the fruit cuticle from the epidermis. Growers may experiment with planting various tolerant pepper cultivars on their farm before they find a cultivar with tolerance to their local $P$. capsici population. New sources of resistance to $P$. capsici, and the development of cultivars with good horticultural characteristics are needed for growers to successfully use host resistance.

Because $P$. capsici populations and physiological races are so diverse, it can be challenging to develop resistant cultivars that hold up to a wide range of isolates (Fig. 7B to D) $(87,127)$. Currently, pepper cultivars tolerant to $P$. capsici perform well in the presence of isolates from some regions, but not with isolates from other regions (30). Future breeding efforts should focus on developing cultivars that display resistance to a set of isolates that encompass the genetic (98) and virulence (44) diversity within $P$. capsici. Host resistance screens are affected by the host type and plant part screened, pathogen culture storage conditions, and the environmental conditions during the screening. Isolates that have been repeat- 
edly subcultured or in long-term storage for years may be weakly virulent or avirulent $(3,44,54,62,77,95)$. Inoculating isolates onto host tissue and then reisolating the pathogen from the host prior to virulence screening may reduce differences in virulence due to repeated subculturing of isolates (44).

Fungicides and biocontrol. When environmental conditions are highly favorable for disease development, none of the currently available fungicides can completely prevent $P$. capsici-caused diseases, and significant losses may be experienced (48). However, in the absence of suitable host resistance, fungicides play an important role in an integrated management strategy for $P$. capsici. While mefenoxam was successfully used for many years to manage the diseases caused by this pathogen, many populations of $P$. capsici are now partially or fully resistant to this fungicide. In areas with resistant pathogen populations, applying mefenoxam is not recommended. Newer products containing dimethomorph, zoxamide (marketed in a mixture with mancozeb), fluopicolide, ametoctradin, mandipropamid, and cymoxanil in combination with famoxadone may be used in alternation with mefenoxam or replace the use of mefenoxam in areas with mefenoxam-resistant pathogen populations. Copper hydroxide provides limited control when used alone, but may be tank-mixed with other fungicides to enhance control, especially in instances when bacterial pathogens also threaten the crop. Alternating fungicides with different modes of action is imperative to delay the development of fungicide resistance. Cyazofamid has shown some efficacy for P. capsici (67), but resistant isolates have already been described in both North Carolina and Georgia (68).

Plants and fruits may develop tolerance to $P$. capsici as they mature $(2,35)$. Fungicide applications should be directed to protect susceptible plant parts. Foliar fungicide sprays are currently used to protect fruit, crown, stem, and leaf tissue. Cucumber fruits are more susceptible than plants, and protecting the fruit, especially the developing fruit (35), is key. Fungicides should be applied when pickling cucumber type fruit are $2.5,5$, and $7.5 \mathrm{~cm}$ long. In addition, fungicides should be applied preventively and just prior to and immediately after rain events. Crown rot is more common than foliar blighting and fruit rot for pepper in the northeastern United States. For control of crown and root rot, crown-directed applications, drip application (Fig. 6C), and drenches $(31,82)$ of fungicides improve disease control as compared to foliar applications (Fig. 6D). However, only fluopicolide is currently labeled for application to the soil through the drip irrigation system (Fig. 6C). Fortunately, populations of $P$. capsici with resistance to this fungicide have not been reported, although isolates from Michigan appear to be less sensitive than isolates from the southeastern United States (60). Fungicides may also be applied to seeds to limit preand postemergence damping-off (5). Recently, red thyme, oregano, and palmarosa essential oils have shown efficacy to protect zucchini fruits and plants against infection by $P$. capsici (9), but the role of essential oils for management of disease in the field has not been elucidated.

In severely infested fields and in fields where only foliar fungicide applications are planned, fumigation can effectively reduce inoculum in the soil and subsequently decrease crown and root rot (Fig. 6D and E). Most fumigants are effective against $P$. capsici if applied when ideal conditions of soil temperature and moisture are maintained during fumigation. Fumigants should be applied to well-aerated soil at 50 to $80 \%$ field moisture capacity that is at a moderate temperature. Fall fumigation is recommended for the northeastern United States because of moderate soil temperatures. Products containing DMDS, metam sodium, metam potassium, 1,3-dichloropropene/chloropicrin, idomethane/chloropicrin, and chloropicrin have been proven effective for disease control in Michigan without crop injury. Fumigants may be applied via injection into the soil or through the drip irrigation system (47). All fumigants need to be sealed in the soil using either a plastic film or a mechanical soil seal for the labeled amount of time and allowed to dissipate before planting to avoid crop injury. In Florida, soil solarization was shown to be as effective as methyl bromide for reducing $P$. capsici populations in the top $10 \mathrm{~cm}$ of the soil, but was not effective to $25 \mathrm{~cm}$ (21). The soil biofumigant Muscodor albus showed some promise in reducing disease when used in conjunction with tolerant host varieties in greenhouse studies. However, no benefit was observed when it was used in combination with a highly susceptible host (19). Future studies testing this and other soil fumigation alternatives in fields infested with $P$. capsici may clarify when biocontrol agents may play a useful role in disease management.

Postharvest rot. Fruits that look healthy at harvest may rot during postharvest storage and transport (48), as P. capsici may have a latent period of $\sim 2$ days before symptom expression (42). Postharvest rot is favored by warm $\left(\sim 25^{\circ} \mathrm{C}\right.$ optimum) and moist conditions (42), and it is recommended that fruits are transported and stored at $\sim 15^{\circ} \mathrm{C}$ following harvest. Wounding has been shown to increase symptom severity in pepper (10) and cucumber fruits (42). Thus, careful handling of fruits may also decrease the possibility of postharvest rot. It has been suggested that washing pits for cucumbers could be a source of postharvest inoculum (43). If wash pits are found to be a source of postharvest inoculum, treatment of this water might be warranted.

\section{Future Prospects}

The occurrence of $P$. capsici in many vegetable-growing regions in the United States has prompted recent research on various aspects of the basic biology of $P$. capsici. However, additional research is needed to further clarify the taxonomy, variations in virulence and pathogenicity among physiological races, and the pathogenicity determinants of the pathogen that underlie the interactions of $P$. capsici with its hosts. A better understanding of
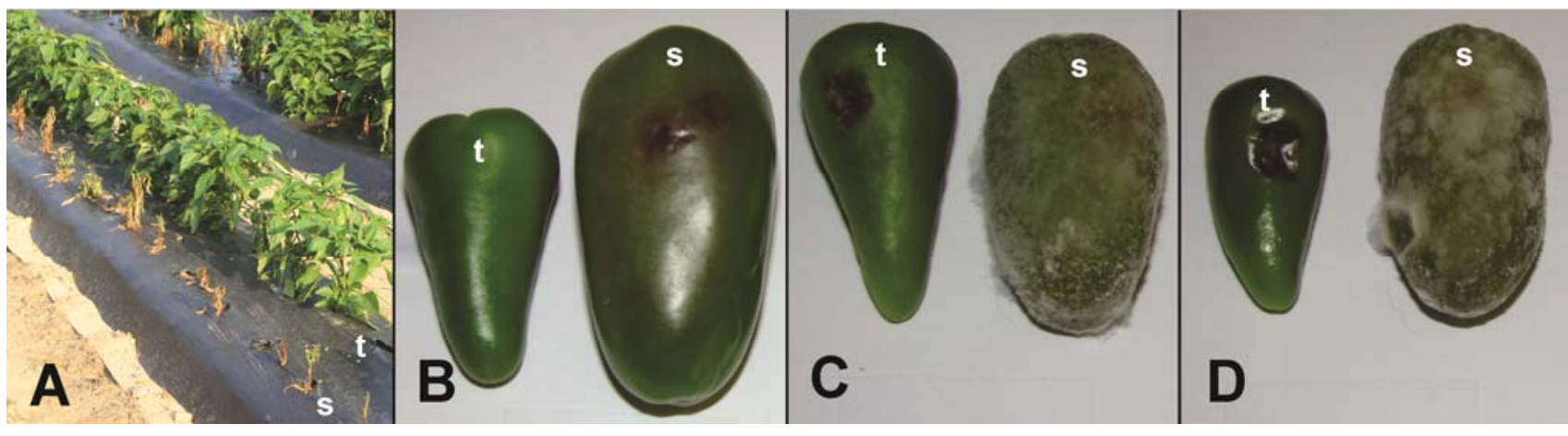

Fig. 7. Some pepper cultivars are tolerant to the diseases caused Phytophthora capsici including root and crown rot (A) and fruit rot (B to D). Susceptibility also depends upon which isolates of $P$. capsici are present (B to D). Some tolerant varieties (t) may still develop disease in the presence of highly virulent isolates, but disease will develop more slowly than in susceptible (s) varieties (C and D). A tolerant ( $t)$ pepper variety is shown on the right and a susceptible variety on the left in $(A)$. A tolerant ( $t$ ) pepper variety is shown on the left and a more susceptible (s) variety on the right in (B to D). 
each of these components will ultimately facilitate the development of durable host resistance and new fungicides that reduce the risk of growing crops susceptible to $P$. capsici.

$P$. capsici is emerging as an oomycete model species due to its fast growth habit, ability to produce abundant asexual spores that can be easily transformed (51), and its heterothallic nature that allows for in vitro crosses for genetic studies (70). Transformation of $P$. capsici has proven useful for investigating the genetic components important for translocation of oomycete avirulence factors into host cells (114). Recently, a high-quality reference draft genome has been developed for P. capsici (Phycall publicly available at: http://genome.jgi-psf.org/) using a hybrid strategy that combined Sanger, 454, and Illumina sequencing (71). In addition to the reference genome, single nucleotide polymorphism (SNP) resources are being developed using field isolates, a $P$. tropicalis isolate recovered from a nursery in Tennessee, and the progeny from a cross between field isolates from Michigan and Tennessee. A focused re-sequencing approach known as restriction site associated DNA (RAD) sequencing was used to identify more than 20,000 SNP markers showing normal Mendelian inheritance across approximately $500 \mathrm{kbp}$ of the $P$. capsici genome (71). Subsets of these markers were used to generate a dense molecular map and will be an important resource for association analysis to study traits such as pathogenicity, virulence, and fungicide resistance. The genome sequencing project has confirmed that $P$. capsici isolates carry tremendous genetic variation in the form of SNPs that can occur as frequently as 1 every $40 \mathrm{bp}$ (71). Overall, the genetic and genomic toolbox for $P$. capsici is growing rapidly, providing an exciting platform to investigate many aspects of oomycete biology.

$P$. capsici is also an ideal model system for students to learn the basic principles of phytopathology due to its ease of recovery from infected plant materials, diversity of spore types, wide host range, and economic importance for states with significant vegetable production.

\section{Acknowledgments}

We thank Rachel Naegele, Jen Foster, Tiffany Enzenbacher, Jarrod Morrice, Michael Meyer, Amanda Gevens, Sofia Windstam, and Brian Cortright for providing some of the photographs featured in this article.

\section{Literature Cited}

1. Ando, K., and Grumet, R. 2006. Evaluation of altered cucumber plant architecture as a means to reduce Phytophthora capsici disease incidence on cucumber fruit. J. Am. Soc. Hortic. Sci. 131:491-498.

2. Ando, K., Hammar, S., and Grumet, R. 2009. Age-related resistance of diverse cucurbit fruit to infection by Phytophthora capsici. J. Am. Soc. Hortic. Sci. 134:176-182.

3. Aragaki, M., and Uchida, J. Y. 2001. Morphological distinctions between Phytophthora capsici and P. tropicalis sp. nov. Mycologia 93:137-145.

4. Babadoost, M. 2000. Outbreak of Phytophthora foliar blight and fruit rot in processing pumpkin fields in Illinois. Plant Dis. 84:1345

5. Babadoost, M., and Islam, S. Z. 2003. Fungicide seed treatment effects on seedling damping-off of pumpkin caused by Phytophthora capsici. Plant Dis. 87:63-68.

6. Barksdale, T. H., Papavizas, G. C., and Johnston, S. A. 1984. Resistance to foliar blight and crown rot of pepper caused by Phytophthora capsici. Plant Dis. 68:506-509.

7. Bartnicki-Garcia, S., and Wang, M. C. 1983. Biochemical aspects of morphogenesis in Phytophthora. Pages 121-137 in: Phytophthora: Its Biology, Taxonomy, Ecology, and Pathology. D. C. Erwin, S. BartnickiGarcia, and P. H. Tsao, eds. American Phytopathological Society, St. Paul, $\mathrm{MN}$.

8. Benson, D. M., and Grand, L. F. 2000. Incidence of Phytophthora root rot of Fraser fir in North Carolina and sensitivity of isolates of Phytophthora cinnamomi to metalaxyl. Plant Dis. 84:661-664.

9. Bi, Y., Jiang, H., Hausbeck, M. K., and Hao, J. J. 2012. Inhibitory effects of essential oils for controlling Phytophthora capsici. Plant Dis. 96:797803 .

10. Biles, C. L., Wall, M. M., Waugh, M., and Palmer, H. 1993. Relationship of Phytophthora fruit rot to fruit maturation and cuticle thickness of New Mexican-type peppers. Phytopathology 83:607-611.

11. Bodine, E. W. 1935. Blight of peppers. Colo. Exp. Stn. Press Bull. 85:6.

12. Bowers, J. H., Martin, F. N., Tooley, P. W., and Luz, E. D. M. N. 2007.
Genetic and morphological diversity of temperate and tropical isolates of Phytophthora capsici. Phytopathology 97:492-503.

13. Bowers, J. H., and Mitchell, D. J. 1989. Variability in virulence of oospore inoculum of Phytophthora capsici and the relationship of the density of oospores in soil to plant mortality. Phytopathology 79:1166.

14. Bowers, J. H., and Mitchell, D. J. 1990. Effect of soil-water matric potential and periodic flooding on mortality of pepper caused by Phytophthora capsici. Phytopathology 80:1447-1450.

15. Bowers, J. H., Papavizas, G. C., and Johnston, S. A. 1990. Effect of soil temperature and soil-water matric potential on the survival of Phytophthora capsici in natural soil. Plant Dis. 74:771-777.

16. Brown, J. G., and Evans, M. N. 1933. A Phytophthora rot of watermelon. Ariz. Agric. Exp. Stn. Tech. Bull. 51:45-65.

17. Cafe-Filho, A. C., and Duniway, J. M. 1996. Effect of location of drip irrigation emitters and position of Phytophthora capsici infections in roots on Phytophthora root rot of pepper. Phytopathology 86:1364-1369.

18. Cafe-Filho, A. C., Duniway, J. M., and Davis, R. M. 1995. Effects of the frequency of furrow irrigation on root and fruit rots of squash caused by Phytophthora capsici. Plant Dis. 79:44-48.

19. Camp, A. R., Dillard, H. R., and Smart, C. D. 2008. Efficacy of Muscodor albus for the control of Phytophthora blight of sweet pepper and butternut squash. Plant Dis. 92:1488-1492.

20. Chellemi, D. O. 2006. Effect of urban plant debris and soil management practices on plant parasitic nematodes, Phytophthora blight and Pythium root rot of bell pepper. Crop Prot. 25:1109-1116.

21. Coelho, L., Chellemi, D. O., and Mitchell, D. J. 1999. Efficacy of solarization and cabbage amendment for the control of Phytophthora spp. in North Florida. Plant Dis. 83:293-299.

22. Davey, J. F., Gregory, N. F., Mulrooney, R. P., Evans, T. A., and Carroll, R. B. 2008. First report of mefenoxam-resistant isolates of Phytophthora capsici from lima bean pods in the mid-Atlantic region. Plant Dis. 92:656.

23. Davidson, C. R., Carroll, R. B., Evans, T. A., Mulrooney, R. P., and Kim, S. H. 2002. First report of Phytophthora capsici infecting lima bean (Phaseolus lunatus) in the Mid-Atlantic region. Plant Dis. 86:1049-1052.

24. Donahoo, R. S., and Lamour, K. H. 2008. Interspecific hybridization and apomixis between Phytophthora capsici and Phytophthora tropicalis. Mycologia 100:911-920.

25. Dunn, A. R., Milgroom, M. G., Meitz, J. C., McLeod, A., Fry, W. E., McGrath, M. T., Dillard, H. R., and Smart, C. D. 2010. Population structure and resistance to mefenoxam of Phytophthora capsici in New York state. Plant Dis. 94:1461-1468.

26. Enzenbacher, T. B., and Hausbeck, M. K. 2012. An evaluation of cucurbit fruits and seedlings to Phytophthora capsici. Plant Dis. 96:1404-1414.

27. Èrsek, T., English, J. T., and Schoelz, J. E. 1995. Creation of species hybrids of Phytophthora with modified host ranges by zoospore fusion. Phytopathology 85:1343-1347.

28. Erwin, D. C., and Ribeiro, O. K. 1996. Phytophthora Diseases Worldwide. American Phytopathological Society, St. Paul, MN, USA.

29. Fernandez-Pavia, S., Biles, C. L., Waugh, M., Onsurez-Waugh, K., Rodriguez-Alvarado, G., and Lidell, C. M. 2004. Characterization of southern New Mexico Phytophthora capsici Leon. isolates from pepper (Capsicum annuum L.). Rev. Mex. Fitopatol. 22:82-89.

30. Foster, J. M., and Hausbeck, M. K. 2010. Resistance of pepper to Phytophthora crown, root, and fruit rot is affected by isolate virulence. Plant Dis. 94:24-30.

31. Foster, J. M., and Hausbeck, M. K. 2010. Managing Phytophthora crown and root rot in bell pepper using fungicides and host resistance. Plant Dis. 94:697-702.

32. French-Monar, R. D., Jones, J. B., Ozores-Hampton, M., and Roberts, P. D. 2007. Survival of inoculum of Phytophthora capsici in soil through time under different soil treatments. Plant Dis. 91:593-598.

33. French-Monar, R. D., Jones, J. B., and Roberts, P. D. 2006 Characterization of Phytophthora capsici associated with roots of weeds on Florida vegetable farms. Plant Dis. 90:345-350.

34. French-Monar, R. D., Patton, A. F., and Isakeit, T. 2009. The occurrence and recent spread of Phytophthora capsici in the Texas High Plains. (Abstr.) Page 11 in: 2nd Int. Phytophthora capsici Conf. Proc.

35. Gevens, A. J., Ando, K., Lamour, K. H., Grumet, R., and Hausbeck, M. K. 2006. A detached cucumber fruit method to screen for resistance to Phytophthora capsici and effect of fruit age on susceptibility to infection. Plant Dis. 90:1276-1282

36. Gevens, A. J., Donahoo, R. S., Lamour, K. H., and Hausbeck, M. K. 2007. Characterization of Phytophthora capsici from Michigan surface irrigation water. Phytopathology 97:421-428.

37. Gevens, A. J., Donahoo, R. S., Lamour, K. H., and Hausbeck, M. K. 2008. Characterization of Phytophthora capsici causing foliar and pod blight of snap bean in Michigan. Plant Dis. 92:201-209.

38. Glosier, B. R., Qgundiwin, E. A., Sidhu, G. S., Sischo, D. R., and Prince, J. P. 2008. A differential series of pepper (Capsicum annuum) lines delineates fourteen physiological races of Phytophthora capsici. Euphytica 162:23-30.

39. Gobena, D., McGrath, M. T., and Lamour, K. 2012. Survival and spread of Phytophthora capsici on Long Island, New York. Mycol. Prog. 11:761768. 


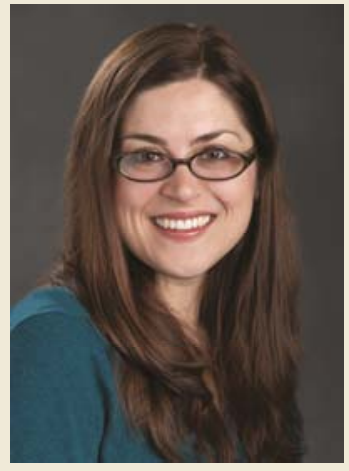

Leah L. Granke

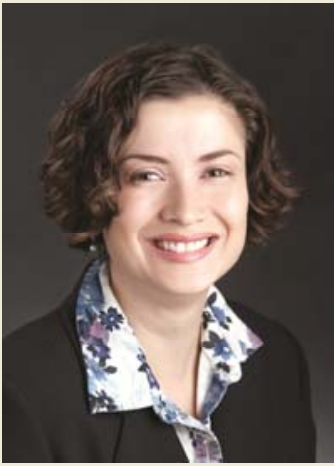

Lina M. QuesadaOcampo

Dr. Granke is a visiting research associate at Michigan State University Department of Plant, Soil, and Microbial Sciences in East Lansing, MI. She received her B.Sc. in biology from Alma College in 2004 and her Ph.D. in plant pathology from Michigan State University in 2010. Her research has focused on the biology and ecology of Phytophthora capsici and other oomycete and fungal pathogens of vegetable crops.

Dr. Quesada is a NIFA postdoctoral fellow in the Department of Plant Biology at Michigan State University. She received her B.S. degrees in microbiology and biology from Universidad de Los Andes, Bogota, Colombia, and her Ph.D. in plant pathology from Michigan State University. Her doctoral work focused on the host range, host resistance, and population structure of Phytophthora capsici. She then was a postdoctoral researcher at the Departments of Plant Pathology and Plant Biology at Michigan State University. Dr. Quesada recently joined the Department of Plant Pathology at North Carolina State University as an assistant professor and extension specialist, where she will be using a combination of traditional and genomic tools to improve management strategies of vegetable diseases.

Dr. Lamour is an associate professor in the Department of Entomology and Plant Pathology at the University of Tennessee, Knoxville. He has studied genetic diversity of Phytophthora for more than a decade and recently led efforts to produce a

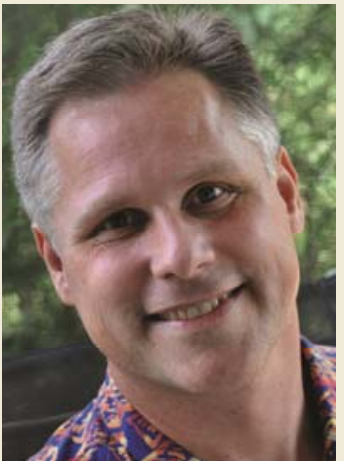

Kurt Lamour

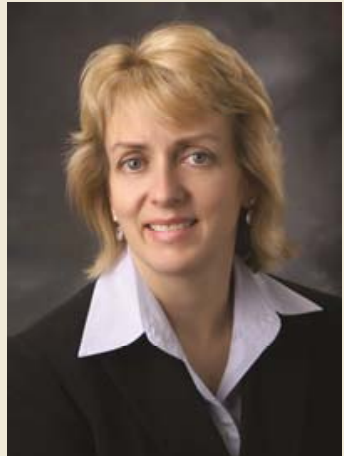

Mary K. Hausbeck high-quality reference genome, a detailed genetic linkage map, and a large battery of single nucleotide polymorphism (SNP) markers for P. capsici. He has collected Phytophthora across North, Central, and South America, Europe, and Asia and looks forward to working with these enigmatic organisms his entire career.

Dr. Hausbeck is a professor in the Department of Plant, Soil and Microbial Sciences at Michigan State University. She received her Ph.D. in plant pathology from Pennsylvania State University. She has worked at Michigan State University since 1990 and has statewide extension (60\%) and research $(40 \%)$ plant pathology responsibilities in vegetables, greenhouse ornamentals, and ginseng. Selected awards she has received include the Excellence in Extension Award from APS, the IR-4 Meritorious Service Award for Service to Michigan and the North Central Region, the Alex Laurie Award for Research and Education from the Society of American Florists, and the Master Farmer Associate Award from the Michigan Vegetable Council. Her current research emphasis includes downy mildews and Phytophthora spp. Additional research projects focus on fungal pathogens affecting floriculture crops, asparagus, onions, and celery. Her overall program goal is to develop novel and integrated disease management strategies for growers and to train graduate students. She has served as major professor for 30 students receiving advanced degrees in plant pathology.
40. Gobena, D., Roig, J., Galmarini, C., Hulvey, J., and Lamour, K. 2012. Genetic diversity of Phytophthora capsici isolates from pepper and pumpkin in Argentina. Mycologia 104:102-107.

41. Goldberg, N. P., and Stanghellini, M. E. 1990. Ingestion-egestion and aerial transmission of Pythium aphanidermatum by shore flies (Ephydrinae: Scatella stagnalis). Phytopathology 80:1244-1246.

42. Granke, L. L., and Hausbeck, M. K. 2010. Effects of temperature, humidity, and wounding on development of Phytophthora rot of cucumber fruit. Plant Dis. 94:1417-1424

43. Granke, L. L., and Hausbeck, M. K. 2010. Effects of temperature, concentration, age, and algaecides on Phytophthora capsici zoospore infectivity. Plant Dis. 94:54-60.

44. Granke, L. L., Quesada-Ocampo, L. M., and Hausbeck, M. K. 2011. Differences in virulence of Phytophthora capsici isolates from a worldwide collection on host fruits. Eur. J. Plant Pathol. 132:281-296.

45. Granke, L. L., Quesada-Ocampo, L. M., and Hausbeck, M. K. 2011. Variation in phenotypic characteristics of Phytophthora capsici isolates from a worldwide collection. Plant Dis. 95:1080-1088.

46. Granke, L. L., Windstam, S. T., Hoch, H. C., Smart, C. D., and Hausbeck, M. K. 2009. Dispersal and movement mechanisms of Phytophthora capsici sporangia. Phytopathology 99:1258-1264.

47. Hausbeck, M. K., Enzenbacher, T. B., Cortright, B. D., and Linderman, S. D. 2012. Phytophthora and fumigation. Michigan State University Ext. Bull.

48. Hausbeck, M. K., and Lamour, K. H. 2004. Phytophthora capsici on vegetable crops: Research progress and management challenges. Plant Dis. 88:1292-1303.

49. Hong, C. X., Richardson, P. A., Kong, P., and Bush, E. A. 2003. Efficacy of chlorine on multiple species of Phytophthora in recycled nursery irrigation water. Plant Dis. 87:1183-1189.
50. Hord, M. J., and Ristaino, J. B. 1992. Effect of the matric component of soil water potential on infection of pepper seedlings in soil infested with oospores of Phytophthora capsici. Phytopathology 82:792-798.

51. Huitema, E., Smoker, M., and Kamoun, S. 2011. A straightforward protocol for electro-transformation of Phytophthora capsici zoospores. Methods Mol. Biol. 712:129-135.

52. Hulvey, J., Hurtado-Gonzalez, O., Aragón-Caballero, L., Gobena, D., Storey, D., Finley, L., and Lamour, K. 2011. Genetic diversity of the pepper pathogen Phytophthora capsici on farms in the Amazonian high jungle of Peru. Am. J. Plant Sci. 2:461-466.

53. Hurtado-Gonzáles, O., Aragon-Caballero, L., Apaza-Tapia, W., Donahoo, R., and Lamour, K. 2008. Survival and spread of Phytophthora capsici in coastal Peru. Phytopathology 98:688-694.

54. Hwang, J. S., and Hwang, B. K. 1993. Quantitative evaluation of resistance of Korean tomato cultivars to isolates of Phytophthora capsici from different geographic areas. Plant Dis. 77:1256-1259.

55. Hyder, N., Coffey, M. D., and Stanghellini, M. E. 2009. Viability of oomycete propagules following ingestion and excretion by fungus gnats, shore flies, and snails. Plant Dis. 93:720-726.

56. Islam, S. Z., Babadoost, M., Lambert, K. N., Ndeme, A., and Fouly, H. M. 2004. Characterization of Phytophthora capsici isolates from processing pumpkin in Illinois. Plant Dis. 89:191-197.

57. Jarvis, W. R., Shipp, J. L., and Gardiner, R. B. 1993. Transmission of Pythium aphanidermatum to greenhouse cucumber by the fungus gnat Bradysia impatiens (Diptera: Sciaridae). Ann. Appl. Biol. 122:23-29.

58. Ji, P., Kone, D., Yin, J., Jackson, K. L., and Csinos, A. S. 2012. Soil amendments with Brassica cover crops for management of Phytophthora blight on squash. Pest. Manag. Sci. 68:639-644.

59. Jiang, Z., Guo, Y. H., Li, S. M., Qi, H. Y., and Guo, J. H. 2006. Evaluation of biocontrol efficiency of different Bacillus preparations and field 
application methods against Phytophthora blight of bell pepper. Biol. Control 36:216-223.

60. Keinath, A. P., and Kousik, C. S. 2011. Sensitivity of isolates of Phytophthora capsici from the eastern United States. Plant Dis. 95:14141419 .

61. Khan, J., Ooka, J. J., Miller, S. A., Madden, L. V., and Hoitink, H. A. J. 2004. Systemic resistance induced by Trichoderma hamatum 382 in cucumber against Phytophthora crown rot and leaf blight. Plant Dis. 88:280-286.

62. Kim, E. S., and Hwang, B. K. 1992. Virulence to Korean pepper cultivars of isolates of Phytophthora capsici from different geographic areas. Plant Dis. 76:486-489.

63. Kim, K. D., Nemec, S., and Musson, G. 1997. Effects of composts and soil amendments on soil microflora and Phytophthora root and crown rot of bell pepper. Crop Prot. 16:165-172.

64. Kim, Y. J., Hwang, B., and Park, K. W. 1989. Expression of age-related resistance in pepper plants infected with Phytophthora capsici. Plant Dis. 73:745-747.

65. Kline, W. L., Wyenandt, C. A., Ward, D. L., Sudal, J. F., and Maxwell, N. L. 2011. Evaluation of six nitrogen fertility programs on marketable yield and development of skin separation in bell pepper fruit. HortTechnology 21:323-328.

66. Ko, W. 1988. Hormonal heterothallism and homothallism in Phytophthora. Annu. Rev. Phytopathol. 26:57-73.

67. Kousik, C. S., Adams, M. L., Jester, W. R., Hassell, R., Harrison, H. F., and Holmes, G. J. 2011. Effect of cultural practices and fungicides on Phytophthora fruit rot of watermelons in the Carolinas. Crop Prot. 30:888894.

68. Kousik, C. S., and Keinath, A. P. 2008. First report of insensitivity to cyazofamid among isolates of Phytophthora capsici from the southeastern United States. Plant Dis. 92:979.

69. LaMondia, J. A., Li, D. W., and Vossbrinck, C. R. 2010. First report of blight of common bean caused by Phytophthora capsici in Connecticut. Plant Dis. 94:134.

70. Lamour, K., and Kamoun, S. 2009. Oomycete Genetics and Genomics: Diversity, Interactions, and Research Tools. John Wiley \& Sons Inc., Hoboken, NJ.

71. Lamour, K., Mudge, J., Gobena, D., Hurtado-Gonzáles, O., Shmutz, J., Kuo, A., Miller, N. A., Rice, B. J., Raffaele, S., Cano, L. M., Bharti, A. K., Donahoo, R. S., Finley, S., Huitema, E., Hulvey, J., Platt, D., Salamov, A., Savidor, A., Sharma, R., Stam, R., Storey, D., Thines, M., Win, J., Haas, B. J., Dinwiddie, D. L., Jenkins, J., Knight, J. R., Affourtit, J. P., Han, C. S., Chertkov, O., Lindquist, E. A., Detter, C., Grigoriev, I. V., Kamoun, S., and Kingsmore, S. K. 2012. Genome sequencing and mapping reveal loss of heterozygosity as a mechanism for rapid adaptation in the vegetable pathogen Phytophthora capsici. Mol. Plant-Microbe Interact. 25:13501360 .

72. Lamour, K. H., and Hausbeck, M. K. 2000. Mefenoxam insensitivity and the sexual stage of Phytophthora capsici in Michigan cucurbit fields. Phytopathology 90:396-400.

73. Lamour, K. H., and Hausbeck, M. K. 2001. Investigating the spatiotemporal genetic structure of Phytophthora capsici in Michigan. Phytopathology 91:973-980.

74. Lamour, K. H., and Hausbeck, M. K. 2002. The spatiotemporal genetic structure of Phytophthora capsici in Michigan and implications for disease management. Phytopathology 92:681-684.

75. Lamour, K. H., and Hausbeck, M. K. 2003. Effect of crop rotation on the survival of Phytophthora capsici in Michigan. Plant Dis. 87:841-845.

76. Latijnhouwers, M., de Wit, P. J., and Govers, F. 2003. Oomycetes and fungi: Similar weaponry to attack plants. Trends Microbiol. 11:462-469.

77. Lee, B. K., Kim, B. S., Chang, S. W., and Hwang, B. K. 2001. Agressiveness to pumpkin cultivars of isolates of Phytopththora capsici from pumpkin and pepper. Plant Dis. 85:497-500.

78. Leonian, L. H. 1922. Stem and fruit blight of peppers caused by Phytophthora capsici sp. nov. Phytopathology 12:401-408.

79. Liu, B., Gumpertz, M. L., Hu, S., and Ristaino, J. B. 2008. Effect of prior tillage and soil fertility amendments on dispersal of Phytophthora capsici and infection of pepper. Eur. J. Plant Pathol. 120:273-287.

80. Luz, E. D. M. N., Cerqueira, A. O., Faleiro, F. G., Dantas Neto, A., Matsuoka, K., and Marques, J. R. B. 2003. Genetic diversity of Phytophthora capsici isolates from different hosts based on RAPD markers, pathogenicity and morphology. (In Portuguese, with English abstract.) Fitopatol. Bras. 28:559-564.

81. Madden, L. V. 1997. Effects of rain splash dispersal of fungal pathogens. Can. J. Plant Pathol. 19:225-230.

82. Matheron, M. E., and Porchas, M. 2008. Efficacy of fungicides for management of the soil phase of Phytophthora blight on pepper plants, 2006. Plant Dis. Manag. Rep. 2:V083. Online publication.

83. McDonald, B. A., and Linde, C. 2002. Pathogen population genetics, evolutionary potential, and durable resistance. Annu. Rev. Phytopathol. 40:349-379.

84. McGrath, M. T. 2009. Phytophthora blight affects snap bean on Long Island, NY. Online publication. http://vegetablemdonline.ppath.cornell. edu/NewsArticles/Bean_phytoJune09.html
85. Mchau, G. R. A., and Coffey, M. D. 1995. Evidence for the existence of two distinct subpopulations in Phytophthora capsici and a redescription of the species. Mycol. Res. 99:89-102.

86. Nesmith, W. Phytophthora diseases of vegetable crops-a wake up call! Online publication. http://www.uky.edu/Ag/kpn/kpn_03/pn030623.htm

87. Oelke, L. M., and Bosland, P. W. 2003. Differentiation of race specific resistance to Phytophthora root rot and foliar blight in Capsicum annuum. J. Am. Soc. Hortic. Sci. 128:213-218.

88. Oudemans, P., and Coffey, M. D. 1991. A revised systematics of twelve papillate Phytophthora species based on isozyme analysis. Mycol. Res. 95:1025-1046.

89. Oudemans, P., and Coffey, M. D. 1991. Relationships between Phytophthora species: Evidence from isozyme analysis. Cambridge University Press, Cambridge.

90. Padley, J. L. D., Kabelka, E. A., and Roberts, P. 2009. Inheritance of resistance to crown rot caused by Phytopthora capsici in Cucurbita. HortScience 44:211-213.

91. Pan, Z. 1997. Investigation of genetic variation in Phytophthora capsici $\mathrm{Ph} . \mathrm{D}$. diss. University of Massachusetts, Amherst.

92. Parra, G., and Ristaino, J. B. 1998. Insensitivity to Ridomil Gold (mefenoxam) found among field isolates of Phytophthora capsici causing Phytophthora blight on bell pepper in North Carolina and New Jersey. Plant Dis. 82:711.

93. Parra, G., and Ristaino, J. B. 2001. Resistance to mefenoxam and metalaxyl among field isolates of Phytophthora capsici causing Phytophthora blight of bell pepper. Plant Dis. 85:1069-1075.

94. Ploetz, R., Heine, G., Haynes, J., and Watson, M. 2001. An investigation of biological attributes that may contribute to the importance of Phytophthora capsici as a vegetable pathogen in Florida. Ann. Appl. Biol. 140:61-67.

95. Polach, F. J., and Webster, R. K. 1972. Identification of strains and inheritance of pathogenicity in Phytophthora capsici. Phytopathology 62:20-26.

96. Quesada-Ocampo, L. M., Fulbright, D. W., and Hausbeck, M. K. 2009. Susceptibility of Fraser fir to Phytophthora capsici. Plant Dis. 93:135-141.

97. Quesada-Ocampo, L. M., Granke, L. L., and Hausbeck, M. K. 2011 Temporal genetic structure of Phytophthora capsici populations from a creek used for irrigation in Michigan. Plant Dis. 95:1358-1369.

98. Quesada-Ocampo, L. M., Granke, L. L., Mercier, M. R., Olsen, J., and Hausbeck, M. K. 2011. Investigating the genetic structure of Phytophthora capsici populations. Phytopathology 101:1061-1073.

99. Quesada-Ocampo, L. M., and Hausbeck, M. K. 2010. Resistance in tomato and wild relatives to crown and root rot caused by Phytophthora capsici. Phytopathology 100:619-627.

00. Reifschneider, F. J. B., Adalberto, C. C. F., and Arildo, M. R. 1986. Factors affecting expression of resistance in pepper (Capsicum annuum) to blight caused by Phytophthora capsici in screening trials. Plant Pathol. 35:451456.

101. Ribeiro, O. K. 1983. Physiology of asexual sporulation and spore germination in Phytophthora. In: Phytophthora: Its Biology, Taxonomy, Ecology, and Pathology. D. C. Erwin, S. Bartnicki-Garcia, and P. H. Tsao, eds. American Phytopathological Society, St. Paul, MN

102. Ristaino, J. B. 1990. Intraspecific variation among isolates of Phytophthora capsici from pepper and cucurbit fields in North Carolina. Phytopathology 80:1253-1259.

103. Ristaino, J. B. 1991. Influence of rainfall, drip irrigation, and inoculum density on the development of Phytophthora root and crown rot epidemics and yield in bell pepper. Phytopathology 81:922-929.

104. Ristaino, J. B., Hord, M. J., and Gumpertz, M. L. 1992. Population densities of Phytophthora capsici in field soils in relation to drip irrigation, rainfall, and disease incidence. Plant Dis. 76:1017-1024.

105. Ristaino, J. B., and Johnston, S. A. 1999. Ecologically based approaches to management of Phytophthora blight on bell pepper. Plant Dis. 83:10801089.

106. Ristaino, J. B., Larkin, R. P., and Campbell, C. L. 1993. Spatial and temporal dynamics of Phytophthora epidemics in commercial bell pepper fields. Phytopathology 83:1312-1320.

107. Ristaino, J. B., Parra, G., and Campbell, C. L. 1997. Suppression of Phytophthora blight in bell pepper by a no-till wheat cover crop. Phytopathology 87:242-249.

108. Roberts, P. D., Urs, R. R., French-Monar, R. D., Hoffine, M. S., Seijo, T. E., and McGovern, R. J. 2005. Survival and recovery of Phytophthora capsici and oomycetes in tailwater and soil from vegetable fields in Florida. Ann. Appl. Biol. 146:351-359.

109. Roe, N. E., Stoffella, P. J., and Bryan, H. H. 1994. Growth and yields of bell pepper and winter squash grown with organic and living mulches. J. Am. Soc. Hortic. Sci. 119:1193-1999.

110. Sandsten, E. P. 1939. Director's annual report. Fifty-second fiscal year, 1938-1939. Colo. Agric. Exp. Stn. Rpt. Page 63.

111. Sang, M. K., Kim, J. G., and Kim, K. D. 2010. Biocontrol activity and induction of systemic resistance in pepper by compost water extracts against Phytophthora capsici. Phytopathology 100:774-783.

112. Satour, M. M., and Butler, E. E. 1968. Comparative morphological and physiological studies of the progenies from intraspecific matings of 
Phytophthora capsici. Phytopathology 58:183-192.

113. Schlub, R. L. 1983. Epidemiology of Phytophthora capsici on bell pepper. J. Agric. Sci., Cambridge 100:7-11.

114. Schornack, S., van Damme, M., Bozkurt, T. O., Cano, L. M., Smoker, M., Thines, M., Gaulin, E., Kamoun, S., and Huitema, E. 2010. Ancient class of translocated oomycete effectors targets the host nucleus. PNAS 107:17421-17426.

115. Silvar, C., Merino, F., and Díaz, J. 2006. Diversity of Phytophthora capsici in northwest Spain: Analysis of virulence, metalaxyl response, and molecular characterization. Plant Dis. 90:1135-1142.

116. Springer, J. K., and Johnston, S. A. 1982. Black polyethylene mulch and Phytophthora blight of pepper. Plant Dis. 66:281.

117. Sy, O., and Bosland, P. W. 2005. Inheritance of Phytophthora stem blight resistance as compared to Phytophthora root rot and foliar blight in Capsicum annuum L. J. Am. Soc. Hortic. Sci. 30:75-78.

118. Tamietti, G., and Valentino, D. 2001. Physiological characterization of a population of Phytophthora capsici Leon. from northern Italy. J. Plant Pathol. 83:199-205.

119. Thabuis, A., Lefebvre, V., Bernard, G., Daubeze, A. M., Phaly, T., Pochard, E., and Palloix, A. 2004. Phenotypic and molecular evaluation of a recurrent selection program for a polygenic resistance to Phytophthora capsici in pepper. Theor. Appl. Genet. 109:342-351.

120. Thabuis, A., Palloix, A., Pflieger, S., Daubeze, A. M., Caranta, C., and Lefebvre, V. 2003. Comparative mapping of Phytophthora resistance loci across Solanaceae and for a large genetic diversity. Theor. Appl. Genet. 106:1473-1485.

121. Tian, D., and Babadoost, M. 2003. Genetic variation among isolates of
Phytophthora capsici from Illinois. (Abstr.) Phytopathology 93:S84.

122. Tian, D., and Babadoost, M. 2004. Host range of Phytophthora capsici from pumpkin and pathogenicity of isolates. Plant Dis. 88:485-489.

123. Tompkins, C. M., and Tucker, C. M. 1937. Phytophthora rot of honeydew melon. J. Agric. Res. 54:933-944.

124. Tompkins, C. M., and Tucker, C. M. 1941. Root rot of pepper and pumpkin caused by Phytophthora capsici. J. Agric. Res. 63:417-426.

125. Tyler, B. M. 2002. Molecular basis of recognition between Phytophthora pathogens and their hosts. Annu. Rev. Phytopathol. 40:137-167.

126. van West, P., Morris, B. M., Reid, B., Appiah, A. A., Osborne, M. C. Campbell, T. A., Shepherd, S. J., and Gow, N. A. R. 2002. Oomycete plant pathogens use electric fields to target roots. Mol. Plant-Microbe Interact. 15:790-798.

127. Walker, S. J., and Bosland, P. W. 1999. Inheritance of Phytophthora root rot and foliar blight resistance in pepper. J. Am. Soc. Hortic. Sci. 124:14-18.

128. Wang, Z., Langston, D. B., Csinos, A. S., Gitaitis, R. D., Walcott, R. R., and Ji, P. 2009. Development of an improved isolation approach and simple sequence repeat marker to characterize Phytophthora capsici populations in irrigation ponds in southern Georgia. Appl. Environ. Microbiol. 75:5467-5473.

129. Weber, G. F. 1932. Blight of peppers in Florida caused by Phytophthora capsici. Phytopathology 22:775-780.

130. Wiant, J. S., and Tucker, C. M. 1940. A rot of winter queen watermelons caused by Phytophthora capsici. J. Agric. Res. 60:73-88.

131. Yin, J., Jackson, K. L., Candole, B. L., Csinos, A. S., Langston, D. B., and Ji, P. 2012. Aggressiveness and diversity of Phytophthora capsici on vegetable crops in Georgia. Ann. Appl. Biol. 160:191-200. 